\title{
Toxicological availability of nickel to the benthic oligochaete Lumbriculus variegatus
}

This is a post-print of a paper published in Environment International (Elsevier, Amsterdam, The Netherlands). The contents are identical to those in the published version.

Full bibliographic citation (please cite as follows):

Vandegehuchte M.B., Roman Y.E., Nguyen L.T.H., Janssen C.R., De Schamphelaere K.A.C. Toxicological availability of nickel to the benthic oligochaete Lumbriculus variegatus. Environment International 33: 746-742.

Link to published journal version (via digital object identifier):

http://dx.doi.org/10.1016/j.envint.2007.02.006 
1 Toxicological availability of nickel to the benthic oligochaete Lumbriculus

2 variegatus

3 Vandegehuchte M.B., Roman Y.E., Nguyen L.T.H., Janssen C.R., De Schamphelaere

4 K.A.C

5

6 Laboratory of Environmental Toxicology and Aquatic Ecology, Ghent University, J.

7 Plateaustraat 22, B-9000 Ghent, Belgium

8

9 Corresponding author: Michiel Vandegehuchte, Laboratory of Environmental

10 Toxicology and Aquatic Ecology, Ghent University, J. Plateaustraat 22, B-9000 Ghent,

11 Belgium. Tel: +32 926437 07, Fax: +32 926437 66, E-mail:

12 Michiel.Vandegehuchte@UGent.be 


\section{Abstract}

15 It is generally accepted that the bioavailability of metals in sediments is influenced by

16 the presence of acid volatile sulfides (AVS). The pore water hypothesis predicts that, if

17 the molar concentration of simultaneously extracted metals (SEM) in a sediment is

18 smaller than the molar concentration of AVS, the free metal ion activity in the pore

19 water is very small and that consequently no metal toxicity in short-term toxicity tests is

20 observed. In this study we examined (1) if this concept can be extended to predict the

21 absence of chronic Ni toxicity to the oligochaete deposit-feeding worm Lumbriculus

22 variegatus and (2) if the organic carbon normalized excess SEM; i.e. [SEM-AVS] $/ f_{O C}$

23 predicts the magnitude of $\mathrm{Ni}$ toxicity to L. variegatus. A 28-day toxicity experiment was

24 performed in which biomass production of L. variegatus was determined in two natural

25 sediments with different $[\mathrm{AVS}]$ and $\mathrm{f}_{\mathrm{OC}}$, spiked at different Ni concentrations. The

26 absence of toxicity is predicted correctly by the $[\mathrm{SEM}-\mathrm{AVS}]<0$ criterion when only the

$27 \quad 0-1 \mathrm{~cm}$ surface layer of the sediment is considered, but not when the whole bulk

28 sediment is considered $(0-3 \mathrm{~cm})$. In both sediments, the same [SEM-AVS]/f $f_{\mathrm{OC}}$ at the

29 surface corresponds with a similar decrease in L. variegatus biomass. Thus, [SEM-

$30 \mathrm{AVS}] / \mathrm{f}_{\mathrm{OC}}$ in the surface layer accurately predicts the magnitude of toxicity. This

31 measure is therefore a good estimator of toxicologically available Ni. On the other hand,

32 the free $\mathrm{Ni}^{2+}$ ion activity in the overlying water appeared to be an equally good predictor

33 of the magnitude of toxicity. Consequently, it was not possible to determine the relative

34 importance of the overlying water and pore water exposure route with the semi-static

35 laboratory experiments. 
37 It has been demonstrated that the simultaneously extracted metals - acid volatile sulfide 38 (SEM-AVS) method is an effective tool in predicting the absence of metal toxicity in sediments in short-term toxicity tests when [SEM-AVS] $<0$ (Di Toro et al., 1990; Di Toro et al., 1992; Casas and Crecelius, 1994; Pesch et al., 1995; Hansen et al., 1996). The underlying principle is that except for pyrite, all other iron and manganese mono sulfides that may be present in sediments have higher solubility products than other metal sulfides. Thus, $\mathrm{Fe}$ and $\mathrm{Mn}$ can be displaced by other divalent metals $(\mathrm{Cu}, \mathrm{Cd}, \mathrm{Ni}$, $\mathrm{Pb}, \mathrm{Zn}$ ) on a mole-to-mole basis. Because these metal sulfides exhibit very low solubility, sediments with an excess of reactive sulfide will exhibit very low dissolved metal concentrations in pore waters and will not cause toxicity (Ankley et al., 1996).

Sediments with excess SEM do not always exhibit toxicity to invertebrate sediment organisms. Organic matter can bind non-sulfide bound trace metals, thus preventing them to enter the dissolved phase (Mahony et al., 1996). Based on this, [SEM-AVS]/ $\mathrm{f}_{\mathrm{OC}}$ has been proposed as a measure of bioavailable metal (Di Toro et al., 2005; Hansen et al., 2005). In a recently proposed biotic ligand model for sediments, it has been shown that $[\mathrm{SEM}-\mathrm{AVS}] / \mathrm{f}_{\mathrm{OC}}$ determines the free metal activity in the pore water(Di Toro et al., 2005). If this value is greater than a critical threshold, sediments are predicted to be toxic.

The $[\mathrm{SEM}-\mathrm{AVS}] / \mathrm{f}_{\mathrm{OC}}$ concept assumes that there is no metal toxicity caused by transformations of the sulfide and organic matter bound metal in the gut of sedimentingesting organisms or via exposure to contaminated food (Meyer et al., 2005). Some

60 authors (Lee B.G., Griscom S.B. et al., 2000; Lee B.G., Lee J.S. et al., 2000) have 
61 observed that benthic organisms can assimilate metals that are associated with sulfides

62 via dietborne exposure. They demonstrated significant bioaccumulation of metals at concentrations where $[\mathrm{SEM}-\mathrm{AVS}]<0$. However, these authors did not measure toxic effects; they assume that dietary exposure as measured by accumulation is related to chronic toxicity (Lee B.G., Griscom S.B. et al., 2000). However, they also note that generic relationships between metal bioaccumulation and toxicity are not well understood. Animal species differ in their abilities to detoxify bioaccumulated metals (e.g. via metallothionein or granule induction) or develop tolerance (Adams et al., 2000; Lee B.G., Lee J.S. et al., 2000). An increase in bioaccumulation may be a sign of active metal uptake and not toxicity in the case of metal deficiency (Muyssen and Janssen, 2002; Bossuyt and Janssen, 2003). Thus, bioaccumulated metals may not always reflect toxic effects (McGeer et al., 2003).

To our knowledge, the applicability of the SEM-AVS concept to predict the absence of chronic, sub-lethal toxicity of nickel to a benthic organism exposed in single-species laboratory toxicity tests has not been demonstrated. In this study, the hypothesis tested is that $\mathrm{Ni}^{2+}$ in the pore water determines chronic toxicity to L. variegatus. In other words, we examined (1) if $[\mathrm{SEM}-\mathrm{AVS}]<0$ predicts the absence of chronic Ni toxicity and (2) if [SEM-AVS]/ $f_{\text {OC }}$ predicts the presence and magnitude of Ni toxicity to $L$.

80 variegatus, independent of sediment characteristics. The vertical profiles of [SEM-

81 AVS] and pore water concentrations were considered, since vertical distributions of

82 AVS and SEM can affect metal toxicity in sediments and pore water metal concentrations (Boothman et al., 2001). Two natural sediments with different characteristics were chosen to test the hypothesis, so that at comparable [SEM], different [AVS] accounted for differences in [SEM-AVS]. Finally, the applicability of 
86 the mentioned sediment-biotic ligand model (sBLM) (Di Toro et al., 2005) will be

87 tested with the data on biomass of Lumbriculus in Ni spiked sediments. In this way, the possible use of the sBLM for chronic single-species toxicity tests with Ni will be

89 evaluated.

90

91 Materials and Methods

92

Sediment sampling, spiking and analysis

94

Two natural sediments were sampled. Brakel sediments were taken by scoop sampling

96 from the banks of a small stream (near the source) in a nature reserve in Brakel,

97 Belgium $\left(50^{\circ} 45^{\prime} \mathrm{N}, 3^{\circ} 46^{\prime} \mathrm{E}\right)$. Water depth at the sampling time was about $50 \mathrm{~cm}$. Ijzer sediments were taken by grab sampling with a Van Veen grab from the Ijzer river, Belgium (about $50^{\circ} 58^{\prime} \mathrm{N}, 2^{\circ} 48^{\prime} \mathrm{E}$ ). This river is situated in a low density farming zone

100 and has a water depth of about one meter. Plastic buckets were filled with $50-70 \%$

101 sediment, after which overlying water was added to the top of the bucket, which was

102 subsequently closed with a plastic lid. After sampling, sediments were frozen at $-20^{\circ} \mathrm{C}$

103 for two days to kill indigenous organisms and subsequently stored at $4{ }^{\circ} \mathrm{C}$ until use.

104 Brakel and Ijzer have a moderate and a high AVS content, respectively, and a low to

105 moderate organic carbon content. Sediment characteristics are provided in Table 1.

106

107 Before spiking, the sediments were cleaned by press sieving with a $0.5 \mathrm{~cm}$ sieve in 108 deaerated $\left(<0.2 \mathrm{mg} \mathrm{O}_{2} / \mathrm{L}\right)$ overlying water from the site of origin. Cleaned sediments 109 were stored at $4{ }^{\circ} \mathrm{C}$ for $48 \mathrm{~h}$ sedimentation, after which the overlying water was carefully

110 poured-off and spiking was started. $\mathrm{Ni}$ was added as a $\mathrm{NiCl}_{2}$-solution (Merck) in 
111 deaerated $\left(<0.2 \mathrm{mg} / \mathrm{L} \mathrm{O}_{2}\right)$ deionised water, which was thoroughly manually mixed with

112 the sediments in airtight sealed plastic bags. Mean measured test concentrations of $\mathrm{Ni}$ in

113 the spiked sediments ranged from 127 to $1458 \mathrm{mg} / \mathrm{kg}$ dry sediment (Brakel) and from

114514 to $3847 \mathrm{mg} / \mathrm{kg}$ dry sediment (Ijzer) (Table2). After spiking with Ni, sediments were

115 placed into glass test vessels and were stabilized/equilibrated for 70 days before test

116 initiation (Simpson et al., 2004). According to Simpson et al. (2004), equilibration of

117 Ni-spiked sediments occurs within 30-70 days. In natural sediments, AVS consists

118 largely of iron sulfides (Lee J.S. et al., 2000). When the spiked $\mathrm{Ni}^{2+}$ binds with AVS,

$119 \mathrm{Fe}^{2+}$ is released from the $\mathrm{Fe}(\mathrm{II}) \mathrm{S}$ phase. $\mathrm{Fe}(\mathrm{II})$ can be lost by diffusion to the oxic layers,

120 where it can be oxidized to solid Fe-hydroxide precipitates. After 43 days for the Brakel

121 sediments and after 58 days for the Ijzer sediments, precipitated $\mathrm{Fe}(\mathrm{OOH})$ was removed

122 by manually scraping it off the top layer. This was done to prevent toxicity due to

123 elevated dissolved $\mathrm{Fe}$ in the pore water and overlying water (Gonzalez, 1996) and to

124 prevent artefacts during the determination of SEM and AVS (Simpson et al., 1998).

126 At test initiation and termination, samples were taken for determination of dry wt,

$127 \% \mathrm{OC}$, total $\mathrm{Ni}$ concentration $\left(\mathrm{Ni}_{\mathrm{T}}\right)$, AVS and $\mathrm{SEM}_{\mathrm{Ni}}$. Overlying water was sampled

128 about $1 \mathrm{~cm}$ above the sediment surface to assess dissolved $\mathrm{Ni}, \mathrm{pH}$, ammonia, hardness,

129 conductivity and dissolved organic carbon (DOC) (Table 3). Pore water was collected at

130 each cm depth by means of inert passive pore water samplers with polyether sulfon

131 membranes, so called mini-peepers (Doig and Liber, 2000). In each chamber, dissolved

$132 \mathrm{Ni}, \mathrm{DOC}, \mathrm{pH}$ and redox potential were measured. Sediment dry weight is defined as the

133 difference between wet and dry sediment (dried $72 \mathrm{~h}$ at $60^{\circ} \mathrm{C}$ ). Organic carbon content

134 was determined by loss on ignition (Egeler et al., 2005). AVS and $\mathrm{SEM}_{\mathrm{Ni}}$ were

135 determined according to the modified diffusion method (Leonard et al., 1996) (5 g 
136 sediment extracted for 1 hour in $60 \mathrm{~mL}$ of $1 \mathrm{~N} \mathrm{HCl})$. Samples were taken with a core (2

$137 \mathrm{~cm}$ diameter) and divided into $1 \mathrm{~cm}$ sediment layers. Cores were taken from a replicate

138 test vessel with overlying water present and subsections of $1 \mathrm{~cm}$ were immediately

139 (within 5 seconds) inserted into the diffusion systems, to prevent oxidation and loss of

140 AVS. Sediment destruction for total metal content was done by acid microwave

141 digestion. Ni was analyzed using flame AAS (Spectra AA 100-Varian) and/or a graphite

142 furnace AAS (Zeeman, SpectrAA300-Varian). The detection limit of the former is 8.7

$143 \mu \mathrm{g} \mathrm{Ni} / \mathrm{L}$. For the lower nickel concentrations, the furnace was used with a detection

144 limit which ranged between 2 and $3.4 \mu \mathrm{g} \mathrm{Ni} / \mathrm{L}$.

146 Test designs

148 Lumbriculus variegatus is an ecologically relevant oligochaete, occurring throughout

149 Europe and the United States (Spencer, 1980). It is an epibenthic/benthic organism

150 subject to contaminant exposure via all routes of concern, including ingestion of

151 sediment particles (Phipps et al., 1993). The test was based on a proposed draft OECD

152 test guideline (Egeler et al., 2005). Organisms were from an in-house culture, with

153 parental organisms provided by Blades Biological LTD (United Kingdom). Biomass per

154 replicate of ten organisms was evaluated as a chronic endpoint integrating growth and

155 survival. L. variegatus reproduces parthenogenetically by fragmentation. Therefore

156 survival sensu stricto cannot be measured by counting the number of organisms at the

157 end of the test. Overlying water was a medium hard reconstituted water composed of

158 the following salts diluted in deionised water: $4 \mathrm{mg} / \mathrm{L} \mathrm{KCl}, 123 \mathrm{mg} / \mathrm{L} \mathrm{MgSO} \cdot 7 \mathrm{H}_{2} \mathrm{O}, 96$

$159 \mathrm{mg} / \mathrm{L} \mathrm{NaHCO}_{3}$ and $6 \mathrm{~g} / \mathrm{L} \mathrm{CaSO}_{4}$ (USEPA, 1985). Sixty to $70 \%$ of the overlying water

160 was renewed twice a week. The temperature was $23+/-2{ }^{\circ} \mathrm{C}$ and a $16: 8$ hours light:dark 
161 regime was applied. Ten adult organisms with complete regeneration of tail or head were

162 added per replicate jar with $400 \mathrm{~g}$ wet sediment and $250 \mathrm{~mL}$ overlying water.

163 Organisms were fed ground Tetramin ${ }^{\mathrm{TM}}$ fish flakes (200 $\mu \mathrm{g}$ per organism per day). Five

164 replicates per concentration were used for biological endpoints, whereas two replicates

165 were used to determine physico-chemical sediment properties. Tests were terminated

166 after 28 days.

167

168 Data treatment

169

170 Concentration - effect curves and $\mathrm{EC}_{50} \mathrm{~s}$ were obtained using the logistic model.

171 Parameter estimates were found by fitting the model to the observed data with a non-

172 linear least squares estimation according to the Levenberg-Marquardt algorithm

173 (Levenberg, 1944; Marquardt, 1963). Lowest observed effect concentrations (LOECs)

174 were based on significant differences $(p<0.05)$ of mean biomass between Ni treatments

175 and control treatments, determined using the Mann-Whitney U test, adjusted for ties.

176 All calculations are based on measured $\mathrm{Ni}$ concentrations. T-tests were performed on

177 the residuals of fitted data for comparison of relationships between biomass and

178 concentration after checking for normality with Kolmogorov-Smirnov goodness-of-fit

179 test and for homogeneity of variances with Levene's test. All significance levels were

180 set at $\mathrm{p}=0.05$. Statistics were performed using Statistica 6.0 software (Statsoft, Tulsa,

181 OK, USA). Speciation calculations were performed with the Windermere Humic

182 Aqueous Model (WHAM) VI version 6.0.8 (Natural Environment Research Council,

183 UK) (Tipping, 1998) or with the Biotic Ligand Model (BLM) version 2.1.2 (Hydroqual,

184 Mahwah, New Jersey), which incorporates WHAM V and with which BLM

185 calculations were performed. 


\section{Results and discussion}

188 In comparison with AVS concentrations in different natural sediments reported in

189 literature (van den Hoop et al., 1997; van den Berg et al., 1998; van den Berg et al.,

190 2001), the sediments tested in this study can be regarded as having a medium and high

191 AVS content. The increase in [AVS] at $\mathrm{t}_{0}$ from the top $\mathrm{cm}$ to the $2-3 \mathrm{~cm}$ sediment

192 section, i.e. from $3.5 \mu \mathrm{mol} / \mathrm{g}$ dry sediment to $13.5 \mu \mathrm{mol} / \mathrm{g}$ dry sediment in Brakel and

193 from $42.1 \mu \mathrm{mol} / \mathrm{g}$ dry sediment to $118.2 \mu \mathrm{mol} / \mathrm{g}$ dry sediment in Ijzer, can be

194 considered as representative for the AVS stratification observed in situ (van den Berg et

195 al., 1998; van den Berg et al., 2001).

197 The LOECs expressed as [SEM-AVS] in the different sediment layers are given in

198 Table 4. In the bulk (whole) core of the IJzer sediment [SEM-AVS] $]_{\text {LOEC,bulk }}$ is $<0$. This

199 means that a significant toxic effect was observed, although the concept predicts that no

200 toxicity is expected at $[\mathrm{SEM}-\mathrm{AVS}]<0$. [SEM-AVS] $<0$ measured on the bulk sediment

201 basis does not predict the absence of chronic toxicity. However, when the surface layer

202 of the sediments is considered $(0-1 \mathrm{~cm})$, [SEM-AVS $]_{\text {LOEC,surface }}>0$, confirming the

203 concept. Following the SEM-AVS concept, this may suggest that the surface layer of

204 the sediment contributes more to the observed toxicity than the deeper sediment layers

205 when [SEM-AVS] $<0$ in the deeper layers. Due to oxidation of AVS, more non-sulfide

206 bound Ni will be present at the surface, resulting in the positive [SEM-AVS] values, as

207 observed for other metals by other authors (DeWitt et al., 1996; Liber et al., 1996).

208 Negative values for [SEM-AVS $]_{\text {surface }}$ were only found at lower Ni concentrations in

209 both sediments, where no significant toxic effect was observed. The use of the SEM-

210 AVS concept for risk assessment procedures or for determining sediment quality criteria 
211 should preferentially consider surface layer-based analyses as an alternative to bulk

212 sample analyses (e.g. $10 \mathrm{~cm}$, (van den Hoop et al., 1997)). Obviously, the potential

213 contribution to toxicity from nickel in the overlying water should not be disregarded

214 either in risk assessment (see also further).

216 In this study, no effect was observed at [SEM-AVS $]_{\text {surface }}<0$. Lee et al.(Lee B.G.,

217 Griscom S.B. et al., 2000; Lee B.G., Lee J.S. et al., 2000) did observe accumulation of

218 metals in clams and marine polychaetes at $[\mathrm{SEM}-\mathrm{AVS}]<0$, explaining this by dietary

219 metal uptake from ingested sediments being the dominant exposure route. These authors

220 assumed, but did not demonstrate, that dietary exposure as measured by

221 bioaccumulation is at least generally related to chronic toxicity (Lee B.G., Griscom S.B.

222 et al., 2000; Lee B.G., Lee J.S. et al., 2000). Possibly, bioaccumulation from the dietary route at $[\mathrm{SEM}-\mathrm{AVS}]<0$ in our study was small enough not to cause significant toxicity.

To investigate the utility of [SEM-AVS]/foC as a measure of toxicologically available

$226 \mathrm{Ni}$, the biomass data of both Brakel and Ijzer sediments were pooled and their

227 relationship with [SEM-AVS]/ $f_{\mathrm{OC}}$ was analyzed. Negative values of [SEM-AVS] $/ \mathrm{f}_{\mathrm{OC}}$ were omitted, following the concept that no toxicity occurs when $[\mathrm{SEM}-\mathrm{AVS}]<0$, as

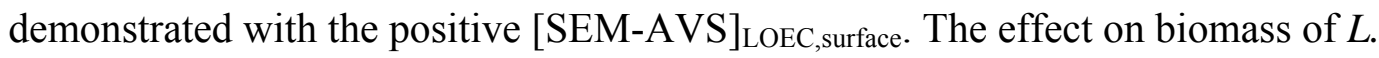
variegatus as a function of [SEM-AVS]/ $f_{\mathrm{OC}}$ in the surface layer, $[\mathrm{SEM}-\mathrm{AVS}] / \mathrm{f}_{\mathrm{OC}}$, surface,

231 showed a similar trend in Brakel and Ijzer sediments. Using the positive values of $232[\mathrm{SEM}-\mathrm{AVS}] / \mathrm{f}_{\mathrm{OC}}$ in the surface layer $(0-1 \mathrm{~cm})$ of the sediments, one concentration-effect curve can be fit to the pooled data of both sediments (Fig. 1a), with the mean of the

234 residuals of both sediments not significantly differing (t-test, $\mathrm{p}=0.14$ ). This indicates

235 that $[\mathrm{SEM}-\mathrm{AVS}] / \mathrm{f}_{\mathrm{OC}}$, or the equivalent $\left(\mathrm{Ni}^{2+}\right)$ in the pore water, is indeed a good 
measure for the toxicologically available Ni. However, using the positive values of

$237[\mathrm{SEM}-\mathrm{AVS}] / \mathrm{f}_{\mathrm{OC}}$ in the deeper layers $(1-2 \mathrm{~cm}$ and $2-3 \mathrm{~cm})$, also one concentration-effect curve can be fit to the pooled data of both sediments, although only one positive value of $[\mathrm{SEM}-\mathrm{AVS}] / \mathrm{f}_{\mathrm{OC}}$ remains for Ijzer (data not shown). This raises the question whether all layers contribute equally to Ni toxicity when there is a positive [SEM-AVS]/f $f_{O C}$. If

241 this is the case, the organisms would be exposed to an average [SEM-AVS]/foC over the

242 entire sediment depth. Those averages were calculated for both sediments, with negative values set to zero, following the concept that this cannot elicit a toxic effect. One concentration-effect curve can be fitted to the pooled data (Fig. 1b), also with the means of the residuals for both sediments not significantly differing (t-test, $p=0.89$ ). The fit is

246 similar $\left(\mathrm{R}^{2}=0.453\right)$ to the fit in Fig. 1a in which surface layer data only are represented $247 \quad\left(\mathrm{R}^{2}=0.402\right)$, indicating that L. variegatus may also be exposed to the deeper layers with lower $[\mathrm{SEM}-\mathrm{AVS}] / \mathrm{f}_{\mathrm{OC}}$. During the test, the organisms were observed to be mainly burrowed in the sediment, down to varying depths of maximum $3 \mathrm{~cm}$.

The difference between the $\mathrm{EC}_{50} \mathrm{~s}$ for biomass in both sediments is reduced from a factor 2.9 when expressed as total $\mathrm{Ni}$ in the bulk sediment ( $\mu \mathrm{g} / \mathrm{g}$ dry sediment) to a factor 1.6 when expressed as $[\mathrm{SEM}-\mathrm{AVS}] / \mathrm{f}_{\mathrm{OC}}$ in the surface layer. According to a t-test comparing the $\mathrm{EC}_{50} \mathrm{~S}$ in both sediments, the factor 2.9 difference is highly significant ( $\mathrm{p}$ $=0.00001)$, while the factor 1.6 difference is not significant $(p=0.51)$. Thus, the same intensity of toxic effect (50\% reduction of growth) is observed at not significantly differing concentrations of [SEM-AVS]/fOC in two different sediments. This suggests again that toxicity to L. variegatus relates to [SEM-AVS] $/ f_{\mathrm{OC}}$ or free $\mathrm{Ni}^{2+}$ in the pore water. These results support the use of $[\mathrm{SEM}-\mathrm{AVS}] / \mathrm{f}_{\mathrm{OC}}$ as a predictor of sediment toxicity. 
262 The concentration of $[\mathrm{SEM}-\mathrm{AVS}] / \mathrm{f}_{\mathrm{OC}}$ determines the free $\left[\mathrm{Ni}^{2+}\right]$ in the pore water (Di

263 Toro et al., 2005). Using the dissolved [Ni] in the pore water of the surface layer of the

264 sediments, one concentration-response curve can be fitted to the pooled data of the

265 Brakel and Ijzer sediments (Fig. 1c). However, this fit was not as good as the one

266 obtained with [SEM-AVS]/foC: there was a significant difference between the residuals

267 of both sediments ( $\mathrm{t}$-test, $\mathrm{p}=0.02$ ). This may be explained by different ratios of

268 dissolved [Ni] and free $\left(\mathrm{Ni}^{2+}\right)$ in the pore water in both sediments, due to different pore

269 water characteristics.

270

271 According to the SEM-AVS concept, due to the small solubility product constants of

272 metal sulfides, sediments with an excess of AVS are expected to have very low metal

273 activity in the pore water (Berry et al., 1996). However, in this study rather high Ni

274 concentrations were found in the pore water of sediment layers in which [SEM - AVS]

275 was smaller than zero . For instance, in the $2-3 \mathrm{~cm}$ horizon of Ijzer, [SEM-AVS] $=-14.5$

$276 \mu \mathrm{mol} / \mathrm{g}$, while $[\mathrm{Ni}]_{\mathrm{PW}}=1221 \mu \mathrm{g} / \mathrm{L}$. This is consistent with Gonzalez (1996)and Doig

277 and Liber (2006), who also observed high [Ni] $]_{\mathrm{PW}}$ at SEM/AVS ratios smaller than one.

278 One possible explanation could be that small colloidal NiS particles passed through the

$2790.45 \mu \mathrm{m}$ peeper membrane and were measured as "dissolved" $\mathrm{Ni}$ in the pore water

280 (Leonard et al., 1999). Another possibility could be that nickel polysulfide complexes or

281 nickel bisulfide $\left(\mathrm{NiHS}^{+}\right)$complexes, which are soluble and do not react with solid $\mathrm{FeS}$

282 to form insoluble NiS, were present (Doig and Liber, 2006). A third possibility would

283 be that the system is not in equilibrium yet, even after the 70 days equilibration period

284 as recommended by Simpson et al. (2004). This last option seems less likely because of

285 the visible $\mathrm{FeOOH}$ precipitate that formed during the equilibration time as described 
above, indicating the replacement of $\mathrm{Fe}$ by $\mathrm{Ni}$ in the FeS. This precipitate did not form

again after it was removed, suggesting that the formation of NiS has ended and equilibrium is achieved.

289

290 The recently proposed sediment-biotic ligand model (sBLM) (Di Toro et al., 2005)

291 predicts the toxicity of sediments based on [SEM-AVS] $/ f_{O C}$, assuming that organic

292 carbon and AVS are the only relevant metal-partitioning phases in sediments. The LOECs expressed as [SEM-AVS]/foC, surface are $122 \mu \mathrm{mol} / \mathrm{g}$ OC and $495 \mu \mathrm{mol} / \mathrm{g}$ OC for

294 Brakel and Ijzer, respectively. These results corroborate the observation that the onset of toxicity occurs at $[\mathrm{SEM}-\mathrm{AVS}] / \mathrm{f}_{\mathrm{OC}} \approx 100 \mu \mathrm{mol} / \mathrm{g}$ OC. This is an empirical observation by Di Toro et al. (2005) based on a series of sediment toxicity data from acute tests with different metals, mainly with marine amphipods and from chronic tests with $\mathrm{Cd}$ and $\mathrm{Zn}$, where effect/no effect was considered as a measure of toxicity in colonization or long term single-species studies. This observation was also made by Burton et al. (2005)for Zn-toxicity in colonization studies with sediments in the field.

302 Specifically for Ni, Di Toro et al. (2005) have, with the sBLM, calculated critical values of $[\mathrm{SEM}-\mathrm{AVS}] / \mathrm{f}_{\mathrm{OC}}$ for a range of water types with varying $\mathrm{pH}$, based on the acute Daphnia critical gill-Ni accumulation. The chronic LOECs in our study, where the average $\mathrm{pH}_{\text {(surface layer) }}$ was 7.6 and 7.1 for Brakel and Ijzer respectively, are lower than

306 the critical acute $\mathrm{Ni}$ concentrations $\left(\mathrm{LC}_{50}\right)$ of $642-1057 \mu \mathrm{mol} / \mathrm{g} \mathrm{OC}$, calculated with the 307 sBLM, in a standard freshwater at pH 7.0 - 8.0 (Di Toro et al., 2005). Thus, our results 308 do not confirm the sBLM as opposed to the studies cited by Di Toro et al. (2005) in 309 which no chronic effects are observed under the lowest calculated (acute) critical value 310 of $[\mathrm{SEM}-\mathrm{AVS}] / \mathrm{f}_{\mathrm{OC}}$. This might be due to the fact that the chronic results from these 
311 study with $\mathrm{Ni}$ and the freshwater organism L. variegatus are lower than the acute results

312 on which Di Toro et al. based their critical values, and/or due to the fact that the

313 Daphnia magna BLM is not applicable to Lumbriculus variegatus due to different

314 sensitivities of both organisms. However, Lumbriculidae are generally less sensitive to

315 metals than Daphnia magna (Von der Ohe and Liess, 2004), and as such one would

316 expect the LOEC to be higher than the sBLM-predicted critical [SEM-AVS]/foc. A

317 critical accumulation was calculated based on the $96 \mathrm{~h} \mathrm{LC50}$ for L. variegatus reported

318 by Schubauer-Berigan et al. (1993). Using this new parameter and the average measured

319 pore water chemistry, the sBLM calculated values of critical [SEM-AVS] $/ \mathrm{f}_{\mathrm{OC}}$ are 2060

$320 \mu \mathrm{mol} / \mathrm{g}$ OC and $1780 \mu \mathrm{mol} / \mathrm{g} \mathrm{OC}$ at a pH of 7.6 (Brakel) and 7.1 (Ijzer), respectively,

321 which is indeed larger than the values based on Daphnia magna sensitivity (Di Toro et

322 al., 2005). Knowing that the acute to chronic ratio for $\mathrm{Ni}$ is about 30 for Daphnia magna

323 (Hunt et al., 2002), it is more likely that the difference between acute and chronic

324 sensitivity is the major cause of the LOECs being lower than the sBLM-predicted

325 critical [SEM-AVS]/foc. The sBLM as applied by Di Toro et al. (2005), does not work

326 for our chronic toxicity data of L. variegatus biomass. The acute Daphnia magna BLM

327 underestimates Ni toxicity in this case and further evaluation of the sBLM for chronic

328 endpoints will be necessary. It is possible, however, that elevated overlying water

329 concentrations at the LOECs in our experiments have a confounding effect on the

330 interpretation of [SEM-AVS]/ $f_{\mathrm{OC}}$, as explained below. This can be another explanation

331 for the observation of LOECs expressed as [SEM-AVS]/f $f_{\mathrm{OC}}$ below model predicted

332 critical values.

333

334 This discussion focused on the $[\mathrm{SEM}-\mathrm{AVS}] / \mathrm{f}_{\mathrm{OC}}$ or $\mathrm{Ni}^{2+}$ in the pore water of the

335 sediments as exposure route for Ni toxicity to L. variegatus. However, it should be 
noted that the Ni concentrations in the overlying water of the tested sediments were

337 elevated in the higher treatments, e.g. mean overlying water concentrations at the LOEC

338 of $248 \mu \mathrm{g} / \mathrm{L} \mathrm{Ni}$ for the Brakel treatment with $544 \mathrm{mg} \mathrm{Ni} / \mathrm{kg}$ dry wt (mean) and 1135

$339 \mu \mathrm{g} / \mathrm{L}$ Ni for the Ijzer treatment with $2234 \mathrm{mg} \mathrm{Ni} / \mathrm{kg}$ dry wt (mean) (Table 2). $\mathrm{Ni}^{2+}$

340 activity in the overlying water, $\left(\mathrm{Ni}^{2+}\right)_{\mathrm{Ow}}$, was calculated with two methods. Firstly,

341 speciation was calculated with WHAM VI, with $\log \mathrm{K}_{\mathrm{MA}}(\mathrm{Ni})=1.75$ and assuming that

342 DOC consists of $40 \%$ active fulvic acid, as the latter was shown to yield a good fit

343 between observed and measured free $\mathrm{Ni}^{2+}$ in natural surface waters (Van Laer et al.,

344 2006). Secondly, speciation calculations were performed following Di Toro et al.

345 (2005), using the BLM software, with the default $\mathrm{pK}_{\mathrm{Ni}-\mathrm{HA}}=2.7$ and 1.4 for humic and

346 fulvic acids respectively and assuming that DOC consists of $84 \%$ humic acid and $16 \%$

347 fulvic acid. To investigate the possibility of exposure to Ni via the overlying water, a

348 concentration-effect curve was fitted to the pooled data of $\left(\mathrm{Ni}^{2+}\right)_{\mathrm{OW}}$ in the overlying

349 water of Brakel and Ijzer sediments (Fig. 2). Only concentrations with a positive [SEM-

$350 \mathrm{AVS}] / \mathrm{f}_{\mathrm{OC}}$, i.e. concentrations where a significant effect was observed, were considered.

351 This yields a good fit with no significant difference between the residuals of both

352 sediments ( $\mathrm{t}$-test, $\mathrm{p}=0.11$ and 0.10 for WHAM VI and BLM speciation respectively).

353 The $\mathrm{EC}_{50}$ as $\left(\mathrm{Ni}^{2+}\right)$ in the overlying water is $9.6 \mu \mathrm{mol} / \mathrm{L}(95 \%$ confidence interval of 6.5

354 to $14.1 \mu \mathrm{mol} / \mathrm{L}$ ) and $4.2 \mu \mathrm{mol} / \mathrm{L}$ (95\% confidence interval of 2.3 to $7.7 \mu \mathrm{mol} / \mathrm{L}$ ) for the

355 WHAM VI and BLM speciation calculations, respectively.

357 The Ni activity in the overlying water is an equally good predictor of toxicity as [SEM-

358 AVS $] / f_{\mathrm{OC}} \cdot$ Thus, it cannot be excluded that Ni in the overlying water is an important part

359 of the toxicologically available Ni in our experiments. 
361 The $\left(\mathrm{Ni}^{2+}\right)$ Ow as calculated with WHAM VI correlated significantly with [SEM-

$362 \mathrm{AVS}] / \mathrm{f}_{\mathrm{OC}}$ in the surface layer $(\mathrm{R}=0.96, \mathrm{p}=0.008)$, but not significantly $(\mathrm{R}=0.84, \mathrm{p}=$

3630.08 ) with the averaged [SEM-AVS]/f OC $_{\mathrm{O}}$ over depth as described above (with negative

$364[\mathrm{SEM}-\mathrm{AVS}] / \mathrm{f}_{\mathrm{OC}}$ set to zero). Similar results were found for $\left(\mathrm{Ni}^{2+}\right)_{\mathrm{OW}}$ as calculated with

365 the BLM. This is not surprising, since the $\mathrm{Ni}$ in the overlying water originates from a

366 flux from the sediment via the pore water in the surface layer to the overlying water. So

367 although the results of this study do not allow to distinguish $\left(\mathrm{Ni}^{2+}\right)_{\mathrm{OW}}$ from $\left(\mathrm{Ni}^{2+}\right)_{\mathrm{PW}}$

$368\left(\mathrm{Ni}^{2+}\right.$ activity in the pore water) as the exposure route of $\mathrm{Ni}$ for L. variegatus, it can be

369 concluded that in these tests, either directly (via pore water) or indirectly (via overlying

370 water $),\left(\mathrm{Ni}^{2+}\right)_{\mathrm{PW}}$ or the equivalent $[\mathrm{SEM}-\mathrm{AVS}] / \mathrm{f}_{\mathrm{OC}}$ determines the toxicologically

371 available Ni for L. variegatus.

372

373 In historically contaminated sediments in the field, pore water concentrations are likely

374 to be higher than overlying water concentrations, due to higher dilution factors than

375 those occurring in the routinely used laboratory test designs: i.e. static renewal. Also,

376 the proportion of nickel in the solid phase will be higher in natural sediments, as nickel

377 does not ordinarily enter sediments in soluble forms, as was the case with this study.

378 Therefore [SEM-AVS]/f $\mathrm{fC}_{\mathrm{OC}}$ is suggested as a measure of bioavailable Ni for risk

379 assessment procedures, provided that overlying water $\left(\mathrm{Ni}^{2+}\right)$ is measured and

380 sufficiently low. More research is needed to establish the relative importance of pore

381 water and overlying water as exposure routes for Ni to L. variegatus. Care should be

382 taken in laboratory experiments with high Ni concentrations in sediment, if the purpose

383 is to test the toxicity of nickel associated with sediment phases (i.e., particles and pore

384 water) and not of the overlying water. 
386 Acknowledgement - The authors wish to thank Leen Van Imp, Jill Van Reybrouck,

387 Emmy Pequeur, Marc Vander Borght and Guido Uyttersprot for technical and analytical

388 assistance. This work was funded by the Nickel Producers Environmental Research

389 Association (NiPERA). Karel De Schamphelaere is supported by a post-doctoral

390 fellowship from the Flanders Scientific Research Fund (FWO-Vlaanderen). Karsten

391 Liber from the University of Saskatchewan is gratefully acknowledged for providing us

392 with the mini-peepers. 
Adams WJ, Conard B, Ethier G, Brix KV, Paquin PR and DiToro DM (2000). "The challenges of hazard identification and classification of insoluble metals and metal substances for the aquatic environment." Human and Ecological Risk Assessment 6(6): 1019-1038.

Ankley GT, Di Toro DM, Hansen DJ and Berry WJ (1996). "Technical basis and proposal for deriving sediment quality criteria for metals." Environmental Toxicology and Chemistry 15(12): 2056-2066.

Berry WJ, Hansen DJ, Mahony JD, Robson DL, Di Toro DM, Shipley BP, Rogers B, Corbin JM and Boothman WS (1996). "Predicting the toxicity of metal-spiked laboratory sediments using acid-volatile sulfide and interstitial water normalizations." Environmental Toxicology and Chemistry 15(12): 2067-2079.

Boothman WS, Hansen DJ, Berry WJ, Robson DL, Helmstetter A, Corbin JM and Pratt SD (2001). "Biological response to variation of acid-volatile sulfides and metals in field-exposed spiked sediments." Environmental Toxicology and Chemistry 20(2): 264-272.

Bossuyt BTA and Janssen CR (2003). "Acclimation of Daphnia magna to environmentally realistic copper concentrations." Comparative Biochemistry and Physiology Part C: Toxicology \& Pharmacology 136: 253-264.

Burton GA, Nguyen LTH, Janssen C, Baudo R, McWilliam R, Bossuyt B, Beltrami M and Green A (2005). "Field validation of sediment zinc toxicity." Environmental Toxicology and Chemistry 24(3): 541-553.

Casas AM and Crecelius EA (1994). "Relationship between Acid Volatile Sulfide and the Toxicity of Zinc, Lead and Copper in Marine-Sediments." Environmental Toxicology and Chemistry 13(3): 529-536.

DeWitt TH, Swartz RC, Hansen DJ, McGovern D and Berry W (1996). "Bioavailability and chronic toxicity of cadmium in sediment to the estuarine amphipod leptocheirus plumulosus." Environmental Toxicology and Chemistry 15(12): 2095-2101.

Di Toro DM, Mahony J, Hansen DJ, Scott KJ, Carlson AR and Ankley GT (1992). "Acid volatile sulfide predicts the acute toxicity of cadmium and nickel in sediments." Environmental Science and Technology 26: 96-101.

Di Toro DM, Mahony JD, Hansen DJ, Scott KJ, Hicks MB, Mayr SM and Redmond MS (1990). "Toxicity of Cadmium in Sediments - the Role of Acid Volatile Sulfide." Environmental Toxicology and Chemistry 9(12): 1487-1502.

Di Toro DM, McGrath JA, Hansen DJ, Berry WJ, Paquin PR, Mathew R, Wu KB and Santore RC (2005). "Predicting sediment metal toxicity using a sediment biotic ligand model: methodology and initial application." Environmental Toxicology and Chemistry 24(10): 2410-2427.

Doig L and Liber K (2000). "Dialysis minipeeper for measuring pore-water metal concentrations in laboratory sediment toxicity and bioavailability tests." Environmental Toxicology and Chemistry 19(12): 2882-2889.

Doig LE and Liber K (2006). "Nickel partitioning in formulated and natural freshwater sediments." Chemosphere 62(6): 968-979.

Egeler P, Meller M, Schallnass H and Gilberg D (2005). Validation of a Sediment Toxicity Test with the Endobenthic Aquatic Oligochaete Lumbriculus 
variegatus by an International Ring Test. Flörsheim/Main, ECTOecotoxicologie GmbH: 192.

Gonzalez AM (1996). "A laboratory-formulated sediment incorporating synthetic Acidvolatile sulfide." Environmental Toxicology and Chemistry 15(12): 2209-2220.

Hansen, DiToro, Berry, Boothman, McGrath and Ankley (2005). Procedures for the Derivation of Equilibrium Partitioning Sediment Benchmarks (ESBs) for the Protection of Benthic Organisms: Metal Mixtures (Cadmium, Copper, Lead, Nickel, Silver and Zinc), US EPA.

Hansen DJ, Berry WJ, Mahony JD, Boothman WS, Di Toro DM, Robson DL, Ankley GT, Ma D, Yan Q and Pesch CE (1996). "Predicting the toxicity of metalcontaminated field sediments using interstitial concentration of metals and acidvolatile sulfide normalizations." Environmental Toxicology and Chemistry 15(12): 2080-2094.

Hunt JW, Anderson BS, Phillips BM, Tjeerdema RS, Puckett HM, Stephenson M, Tucker DW and Watson D (2002). "Acute and chronic toxicity of nickel to marine organisms: Implications for water quality criteria." Environmental Toxicology and Chemistry 21(11): 2423-2430.

Lee BG, Griscom SB, Lee JS, Choi HJ, Koh CH, Luoma SN and Fisher NS (2000). "Influences of dietary uptake and reactive sulfides on metal bioavailability from aquatic sediments." Science 287(5451): 282-284.

Lee BG, Lee JS, Luoma SN, Choi HJ and Koh CH (2000). "Influence of acid volatile sulfide and metal concentrations on metal bioavailability to marine invertebrates in contaminated sediments." Environmental Science \& Technology 34(21): 4517-4523.

Lee JS, Lee BG, Luoma SN, Choi HJ, Koh CH and Brown CL (2000). "Influence of acid volatile sulfides and metal concentrations on metal partitioning in contaminated sediments." Environmental Science \& Technology 34(21): 45114516.

Leonard EN, Cotter AM and Ankley GT (1996). "Modified Diffusion Method for analysis of acid volatile sulfides and simultaneously extracted metals in freshwater sediment." Environmental Toxicology and Chemistry 15(9): 14791481.

Leonard EN, Mount DR and Ankley GT (1999). "Modification of metal parititioning by supplementing acid volatile sulfide in freshwater sediments." Environmental Toxicology and Chemistry 18(5).

Levenberg K (1944). "A method for the solution of certain non-linear problems in least squares." Quarterly Journal of Applied Mathematics 2: 164-168.

Liber K, Call DJ, Markee TP, Schmude KL, Balcer MD, Whiteman FW and Ankley GT (1996). "Effects of acid-volatile sulfide on zinc bioavailability and toxicity to benthic macroinvertebrates: A spiked-sediment field experiment." Environmental Toxicology and Chemistry 15(12): 2113-2125.

Mahony JD, Di Toro DM, Gonzalez AM, Curto M and Dilg M (1996). "Partitioning of metals to sediment organic carbon." Environmental Toxicology and Chemistry 15(12): 2187-2197.

Marquardt DW (1963). "An algorithm for least-squares estimation of non-linear parameters." Journal of the Society of Industrial and Applied Mathematics 11: 431-444.

McGeer JC, Brix KV, Skeaff JM, DeForest DK, Brigham SI, Adams WJ and Green A (2003). "Inverse relationship between bioconcentration factor and exposure concentration for metals: Implications for hazard assessment of metals in the 
aquatic environment." Environmental Toxicology and Chemistry 22(5): 10171037.

Meyer J, Adams W, Brix K, Luoma S, Mount D, Stubblefield W and Wood C (2005). Toxicity of Dietborne Metals to Aquatic Organisms. Pensacola, SETAC. Muyssen BTA and Janssen CR (2002). "Accumulation and regulation of zinc in Daphnia magna: links with homeostasis and toxicity." Archives of Environmental Contamination and Toxicology 43: 492-496.

Pesch CE, Hansen DJ, Boothman WS, Berry WJ and Mahony JD (1995). "The role of acid-volatile sulfide and interstitial water metal concentrations in determining bioavailability of cadmium and nickel from contaminated sediments to the marine polychaete Neanthes arenaceodentata." Environmental Toxicology and Chemistry 14(1): 129-141.

Phipps GL, Ankley GT, Benoit DA and Matton VR (1993). "Use of the aquatic oligochaete Lumbriculus variegatus for assessing the toxicity and bioaccumulation of sediment-associated contaminants." Environmental Toxicology and Chemistry 12: 269-279.

Schubauer-Berigan MK, Dierkes JR, Monson PD and Ankley GT (1993). "pHdependent toxicity of $\mathrm{Cd}, \mathrm{Cu}, \mathrm{Ni}, \mathrm{Pb}$ and $\mathrm{Zn}$ to Ceriodaphnia dubia, Pimephales promelas, Hyalella azteca and Lumbriculus variegatus." Environmental Toxicology and Chemistry 12: 1261-1266.

Simpson SL, Angel BM and Jolley DF (2004). "Metal equilibration in laboratorycontaminated (spiked) sediments used for the development of whole-sediment toxicity tests." Chemosphere 54: 597-609.

Simpson SL, Apte SC and Batley GE (1998). "Effect of Short-Term Resuspension Events on Trace Metal Speciation in Polluted Anoxic Sediments." Environmental Science \& Technology 32: 620-625.

Spencer DR (1980). The aquatic oligochaetes of the St. Lawrence Great Lakes region. Proceedings of the First International Symposium on Aquatic Oligochaete Biology. R. O. Brinkhurst, Cook, D.G. New York, Plenum Press.

Tipping E (1998). "Humic ion-binding model VI: An improved description of the interactions of protons and metal ions with humic substances." Aquatic Geochemistry 4(1): 3-48.

USEPA (1985). Methods for Measuring the Acute Toxicity of Effluents to Freshwater and Marine Organisms. Cincinnati, USEPA.

van den Berg GA, Buykx SEJ, van den Hoop MAGT, van der Heijdt LM and Zwolsman JJG (2001). "Vertical profiles of trace metals and acid-volatile sulphide in a dynamic sedimentary environment: Lake Ketel, The Netherlands." Applied Geochemistry 16: 781-791.

van den Berg GA, Loch JPG, van der Heijdt LM and Zwolsman JJG (1998). "Vertical distribution of acid-volatile sulfide and simultaneously extracted metals in a recent sedimentation area of the river meuse in the Netherlands." Environmental Toxicology and Chemistry 17(4): 758-763.

van den Hoop MAGT, den Hollander HA and Kerdijk HN (1997). "Spatial and seasonal variations of acid volatile sulphide (AVS) and simultaneously extracted metals (SEM) in Dutch marine and freshwater sediments." Chemosphere 35(10): 23072316.

Van Laer L, Smolders E, Degryse F, Janssen C and De Schamphelaere KAC (2006). "Speciation of nickel in surface waters measured with the Donnan membrane technique." Analytica Chimica Acta 578(2): 195-202. 
Von der Ohe PC and Liess M (2004). "Relative sensitivity distribution of aquatic invertebrates to organic and metal compounds." Environmental Toxicology and Chemistry 23(1): 150-156. 
544 Table 1 - Sediment characteristics of Brakel and Ijzer sediments: [AVS] in the control treatments at $t_{0}$ (test initiation) per horizontal layer under the surface, average mass fraction of organic carbon in the tested sediments $\left(f_{O C}\right)$ and particle size distribution.

\begin{tabular}{|c|c|c|c|c|c|c|c|}
\hline \multirow{2}{*}{ Sediment } & \multicolumn{3}{|c|}{ [AVS] (mmol/kg dry wt) } & \multirow{2}{*}{$f_{o c}$} & \multirow{2}{*}{$\%$ sand } & \multirow{2}{*}{$\%$ silt } & \multirow{2}{*}{$\%$ clay } \\
\hline & $0-1 \mathrm{~cm}$ & $1-2 \mathrm{~cm}$ & $2-3 \mathrm{~cm}$ & & & & \\
\hline Brakel & 3.5 & 9.9 & 13.5 & 0.0221 & 62.9 & 24.5 & 12.7 \\
\hline ljzer & 42.1 & 104.3 & 118.0 & 0.0395 & 23.9 & 46.4 & 29.6 \\
\hline
\end{tabular}


Table 2: Measured concentrations of total Ni in the sediment, [Ni $]_{\mathrm{Ow}}$ (dissolved Ni in the overlying water), [SEM-AVS] and [Ni $]_{\mathrm{PW}}$ (dissolved $\mathrm{Ni}$ in the pore water) of Brakel and Ijzer sediments, at the beginning $\left(\mathrm{t}_{0}\right)$ and at the end ( $\left.\mathrm{t}_{\text {end }}\right)$ of the 28 day test period, for the different tested concentrations, per horizontal layer when applicable and mean biomass per replicate of $L$. variegatus at the end of the test period, expressed as \% of the mean biomass per replicate in the control treatments

\section{Brake}

\begin{tabular}{|c|c|c|c|c|c|c|c|c|c|c|c|c|c|c|c|c|c|}
\hline \multirow{3}{*}{$\begin{array}{l}\text { Treat- } \\
\text { ment }\end{array}$} & \multirow{2}{*}{\multicolumn{2}{|c|}{$\begin{array}{c}\text { Total Ni } \\
\text { (mg/kg dry } \\
\text { wt) }\end{array}$}} & \multirow{2}{*}{\multicolumn{2}{|c|}{$[\mathrm{Ni}]_{\mathrm{ow}}(\mu \mathrm{g} / \mathrm{L})$}} & \multicolumn{6}{|c|}{ [SEM-AVS] ( $\mu \mathrm{mol} / \mathrm{g}$ dry $w \mathrm{t})$} & \multicolumn{6}{|c|}{$[\mathrm{Ni}]_{\mathrm{PW}}(\mu \mathrm{g} / \mathrm{L})$} & \multirow{3}{*}{$\begin{array}{c}\text { Biomass } \\
\text { ( } \% \text { of } \\
\text { control) } \\
t_{\text {end }} \\
\end{array}$} \\
\hline & & & & & \multicolumn{2}{|c|}{$0-1 \mathrm{~cm}$} & \multicolumn{2}{|c|}{$1-2 \mathrm{~cm}$} & \multicolumn{2}{|c|}{$2-3 \mathrm{~cm}$} & \multicolumn{2}{|c|}{$0-1 \mathrm{~cm}$} & \multicolumn{2}{|c|}{$1-2 \mathrm{~cm}$} & \multicolumn{2}{|c|}{$2-3 \mathrm{~cm}$} & \\
\hline & $t_{0}$ & $t_{\text {end }}$ & $\mathrm{t}_{0}$ & $t_{\text {end }}$ & $t_{0}$ & $t_{\text {end }}$ & $t_{0}$ & $t_{\text {end }}$ & $t_{0}$ & $t_{\text {end }}$ & $t_{0}$ & $t_{\text {end }}$ & $t_{0}$ & $t_{\text {end }}$ & $t_{0}$ & $t_{\text {end }}$ & \\
\hline control & 8 & 5 & 7 & 3 & -3.4 & -1.5 & -9.9 & -5.9 & -13.4 & -10.3 & 11 & 32 & 12 & 17 & 28 & 17 & 100 \\
\hline $\mathrm{C} 1$ & 132 & 122 & 22 & 24 & -2.2 & -1.4 & -8.3 & -7.4 & -12.2 & -7.9 & ND & 128 & ND & 62 & 51 & 48 & 85.9 \\
\hline C2 & 201 & 179 & 21 & 35 & -4.7 & -3.4 & -7.9 & -8.8 & -8.7 & -5.7 & ND & 385 & 64 & 100 & 47 & 126 & 89.1 \\
\hline C3 & 547 & 540 & 263 & 233 & 1.8 & 3.6 & 0.9 & 0.9 & 0.9 & 1.0 & 351 & 1949 & 550 & 603 & 219 & 270 & 67.1 \\
\hline C4 & 1075 & 1068 & 941 & 967 & 12.6 & 14.1 & 7.1 & 10.8 & 9.4 & 9.6 & 1370 & ND & 1542 & 3343 & 3959 & ND & 39.9 \\
\hline C5 & 1544 & 1373 & 1986 & 2034 & 15.5 & 20.6 & 19.1 & 18.8 & 20.3 & 17.6 & 23000 & 8122 & 24177 & 7740 & 37474 & 10532 & 37.9 \\
\hline
\end{tabular}

Ijzer

\begin{tabular}{|c|c|c|c|c|c|c|c|c|c|c|c|c|c|c|c|c|c|}
\hline \multirow{3}{*}{$\begin{array}{l}\text { Treat- } \\
\text { ment }\end{array}$} & \multirow{2}{*}{\multicolumn{2}{|c|}{$\begin{array}{c}\text { Total Ni } \\
\text { (mg/kg dry } \\
\text { wt) }\end{array}$}} & \multirow{2}{*}{\multicolumn{2}{|c|}{$[\mathrm{Ni}]_{\text {ow }}(\mu \mathrm{g} / \mathrm{L})$}} & \multicolumn{6}{|c|}{ [SEM-AVS] ( $\mu \mathrm{mol} / \mathrm{g}$ dry wt) } & \multicolumn{6}{|c|}{$[\mathrm{Ni}]_{\mathrm{PW}}(\mu \mathrm{g} / \mathrm{L})$} & \multirow{3}{*}{$\begin{array}{c}\text { Biomass } \\
\text { ( } \% \text { of } \\
\text { control) } \\
t_{\text {end }}\end{array}$} \\
\hline & & & & & \multicolumn{2}{|c|}{$0-1 \mathrm{~cm}$} & \multicolumn{2}{|c|}{$1-2 \mathrm{~cm}$} & \multicolumn{2}{|c|}{$2-3 \mathrm{~cm}$} & \multicolumn{2}{|c|}{$0-1 \mathrm{~cm}$} & \multicolumn{2}{|c|}{$1-2 \mathrm{~cm}$} & \multicolumn{2}{|c|}{$2-3 \mathrm{~cm}$} & \\
\hline & $t_{0}$ & $t_{\text {end }}$ & $\mathrm{t}_{0}$ & $t_{\text {end }}$ & $t_{0}$ & $t_{\text {end }}$ & $t_{0}$ & $t_{\text {end }}$ & $t_{0}$ & $t_{\text {end }}$ & $\mathrm{t}_{0}$ & $t_{\text {end }}$ & $t_{0}$ & $t_{\text {end }}$ & $t_{0}$ & $t_{\text {end }}$ & \\
\hline control & 8 & 16 & 13 & 19 & -42.0 & -24.0 & -104.2 & -86.6 & -118.1 & -87.6 & 6 & 7 & 16 & 11 & 13 & 10 & 100 \\
\hline $\mathrm{C} 1$ & 460 & 567 & 36 & 46 & -39.4 & -22.7 & -109.7 & -66.9 & -111.6 & -83.0 & 664 & 205 & 62 & 254 & 94 & 63 & 105.9 \\
\hline $\mathrm{C} 2$ & 759 & 905 & 117 & 88 & -47.1 & -37.0 & -109.2 & -77.8 & -104.2 & -75.8 & 924 & ND & 146 & ND & 57 & 205 & 88.4 \\
\hline C3 & 1486 & 1484 & 346 & 209 & -13.5 & 3.8 & -51.5 & -49.6 & -60.2 & -48.4 & 985 & 695 & 1441 & 608 & 2284 & 499 & 72.1 \\
\hline $\mathrm{C} 4$ & 2271 & 2197 & 1141 & 1128 & 11.9 & 27.1 & -14.1 & -16.0 & -14.1 & -14.5 & 3492 & 2171 & 4649 & 1124 & 4689 & 1221 & 54.1 \\
\hline C5 & 3664 & 4031 & 2734 & 2383 & 31.5 & 49.5 & 9.1 & 27.3 & 20.7 & 23.4 & 10718 & 3412 & ND & 4963 & ND & 4847 & 41.8 \\
\hline
\end{tabular}


Table 3 - Overlying water characteristics per treatment for the Brakel and Ijzer sediment tests: $\mathrm{pH}$, dissolved Ca and $\mathrm{Mg}$ and $\mathrm{DOC}$, at the beginning $\left(\mathrm{t}_{0}\right)$ and at the end $\left(\mathrm{t}_{\mathrm{end}}\right)$ of the 28 day test period.

\begin{tabular}{|c|c|c|c|c|c|c|c|c|}
\hline \multicolumn{9}{|c|}{ Brakel } \\
\hline \multirow{2}{*}{ Treatment } & \multicolumn{2}{|c|}{$\mathrm{pH}$} & \multicolumn{2}{|c|}{ [Ca] (mg/L) } & \multicolumn{2}{|c|}{ [Mg] (mg/L) } & \multicolumn{2}{|c|}{ [DOC] (mg/L) } \\
\hline & $\mathrm{t}_{0}$ & $t_{\text {end }}$ & $t_{0}$ & $t_{\text {end }}$ & $\mathrm{t}_{0}$ & $t_{\text {end }}$ & $\mathrm{t}_{0}$ & $t_{\text {end }}$ \\
\hline control & 8.03 & 7.90 & 36.58 & 39.06 & 11.88 & 14.02 & 1.318 & 1.670 \\
\hline $\mathrm{C} 1$ & 7.94 & 7.82 & 33.53 & 32.96 & 9.86 & 13.01 & 1.067 & 4.844 \\
\hline $\mathrm{C} 2$ & 8.17 & 7.83 & 33.80 & 34.64 & 10.11 & 12.89 & 1.173 & 1.884 \\
\hline $\mathrm{C} 3$ & 7.82 & 7.65 & 27.88 & 26.65 & 8.21 & 11.58 & 1.013 & 2.012 \\
\hline $\mathrm{C} 4$ & 7.87 & 7.57 & 29.11 & 25.51 & 8.37 & 11.28 & 1.118 & 2.752 \\
\hline $\mathrm{C} 5$ & 7.69 & 7.51 & 30.06 & 24.66 & 8.35 & 11.15 & 1.369 & 1.726 \\
\hline \multicolumn{9}{|c|}{ ljzer } \\
\hline \multirow{2}{*}{ Treatment } & \multicolumn{2}{|c|}{ pH } & \multicolumn{2}{|c|}{ [Ca] (mg/L) } & \multicolumn{2}{|c|}{ [Mg] (mg/L) } & \multicolumn{2}{|c|}{ [DOC] (mg/L) } \\
\hline & $\mathrm{t}_{0}$ & $t_{\text {end }}$ & $t_{0}$ & $t_{\text {end }}$ & $\mathrm{t}_{0}$ & $t_{\text {end }}$ & $t_{0}$ & $t_{\text {end }}$ \\
\hline control & 7.70 & 7.99 & 36.29 & 48.29 & 15.952 & 12.877 & 1.067 & 2.403 \\
\hline $\mathrm{C} 1$ & 7.89 & 8.03 & 35.95 & 41.59 & 15.23 & 11.776 & 1.228 & 2.032 \\
\hline $\mathrm{C} 2$ & 7.63 & 7.77 & 30.85 & 23.13 & 12.631 & 7.899 & 1.226 & 2.547 \\
\hline $\mathrm{C} 3$ & 7.40 & 7.63 & 32.84 & 25.26 & 13.91 & 8.343 & 1.539 & 2.471 \\
\hline $\mathrm{C} 4$ & 7.43 & 7.42 & 33.33 & 26.33 & 13.586 & 8.37 & 1.345 & 1.934 \\
\hline C5 & 7.40 & 7.37 & 37.70 & 25.26 & 13.479 & 7.965 & 1.424 & 2.23 \\
\hline
\end{tabular}


Table 4 - LOECs for biomass/replicate of $L$. variegatus in Brakel and Ijzer sediments expressed as [SEM-AVS] ( $\mu$ mol Ni/g dry sediment) at different depths below the sediment surface at the beginning $\left(\mathrm{t}_{0}\right)$ and at the end $\left(\mathrm{t}_{\text {end }}\right)$ of the test, as well as the mean of the [SEM$\mathrm{AVS}]_{\text {LOEC }}$ at $t_{0}$ and $t_{\text {end }}$

\begin{tabular}{|c|c|c|c|c|c|c|}
\hline & \multicolumn{3}{|c|}{ Brakel } & \multicolumn{3}{|c|}{ ljzer } \\
\hline & $\begin{array}{c}\text { LOEC as [SEM- } \\
\text { AVS] at } t_{0}\end{array}$ & $\begin{array}{c}\text { LOEC as [SEM- } \\
\text { AVS] at } t_{\text {end }}\end{array}$ & $\begin{array}{c}\text { mean LOEC as } \\
\text { [SEM-AVS] }\end{array}$ & $\begin{array}{c}\text { LOEC as [SEM- } \\
\text { AVS] at } t_{0}\end{array}$ & $\begin{array}{c}\text { LOEC as [SEM- } \\
\text { AVS] at } t_{\text {end }}\end{array}$ & $\begin{array}{c}\text { mean LOEC as } \\
{[\text { SEM-AVS] }}\end{array}$ \\
\hline $\begin{array}{l}\text { Total core, } \\
0-3 \mathrm{~cm}\end{array}$ & -0.4 & 1.5 & 0.6 & -9.6 & -7.4 & -8.5 \\
\hline $\begin{array}{l}\text { A-horizon, } \\
0-1 \mathrm{~cm}\end{array}$ & 1.8 & 3.7 & 2.7 & 11.9 & 27.1 & 19.5 \\
\hline $\begin{array}{l}\text { B-horizon, } \\
1-2 \mathrm{~cm}\end{array}$ & 0.9 & 0.9 & 0.9 & -14.1 & -16.0 & -15.0 \\
\hline $\begin{array}{l}\text { C-horizon, } \\
2-3 \mathrm{~cm}\end{array}$ & 0.9 & 1.0 & 0.9 & -14.1 & -14.5 & -14.3 \\
\hline
\end{tabular}




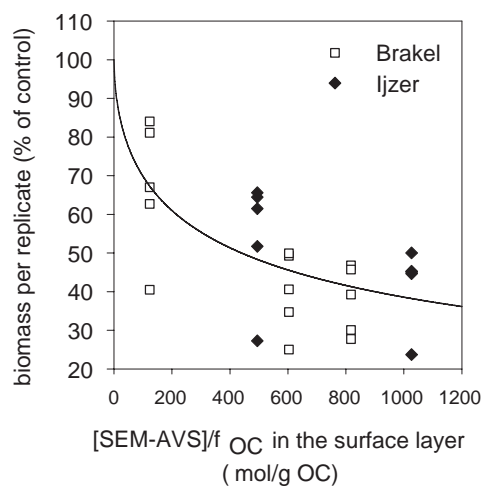

(a)

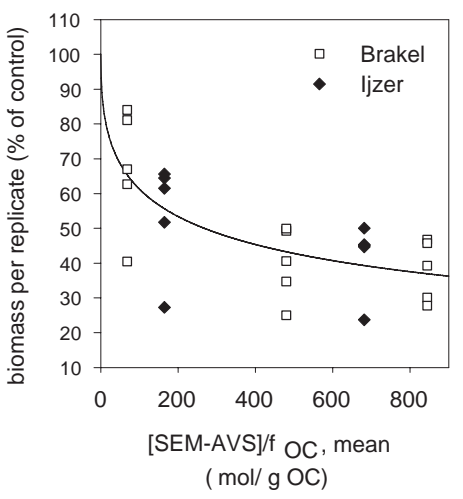

(b)

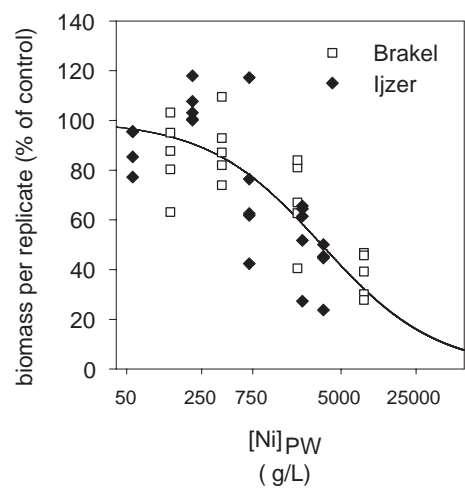

(c)

Figure 1: (a) Concentration - effect curve of biomass per replicate as a function of mean [SEM-AVS]/foc in the surface layer of Brakel and Ijzer; (b) Concentration effect curve of biomass per replicate as a function of mean [SEM-AVS] $/ \mathrm{fOC}_{\mathrm{OC}}$ as mean of the three sediment layers (0-1, 1-2 and 2-3 cm depth) of Brakel and Ijzer; (c) Concentration - effect curve of biomass per replicate as a function of dissolved [Ni] in the pore water of the surface layer of Brakel and Ijzer at the end of the test 


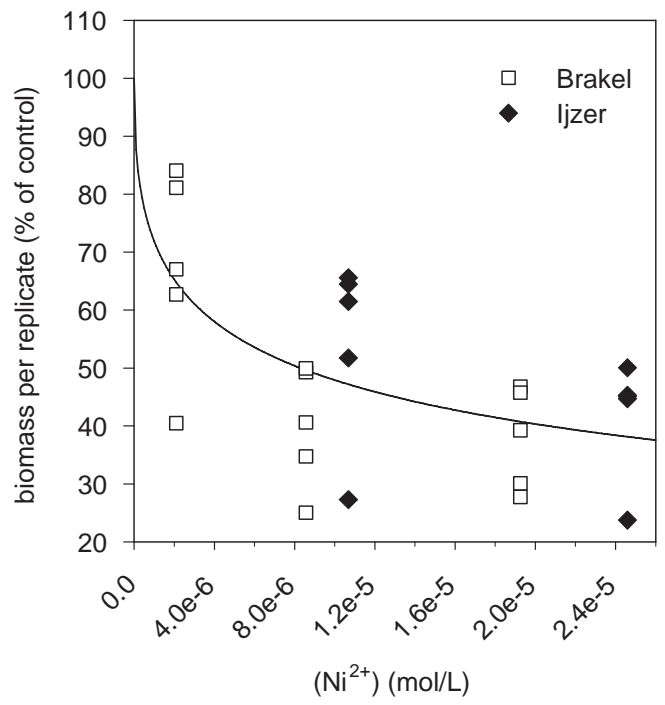

(a)

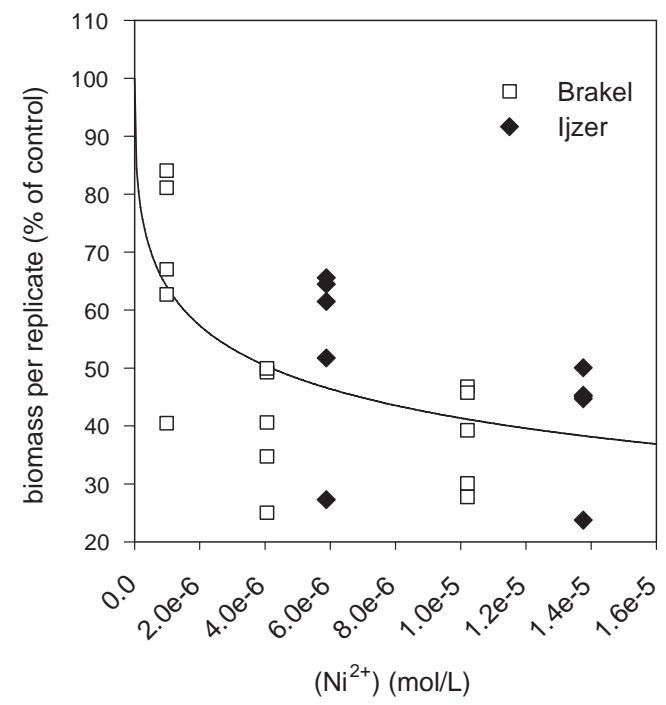

(b)

Figure 2: (a) Concentration-effect curve of biomass per replicate as a function of the mean $\mathrm{Ni}^{2+}$ activity as calculated with WHAM VI (see text) in the overlying water of those concentrations with positive [SEM-AVS] of Brakel and Ijzer sediments; (b) Concentration-effect curve of biomass per replicate as a function of the mean $\mathrm{Ni}^{2+}$ activity as calculated with the BLM speciation programme (see text) in the overlying water of those concentrations with positive [SEM-AVS] of Brakel and Ijzer sediments. 